\title{
The effect of biostimulants on virus-infected grapevine maintained in greenhouse conditions
}

\author{
I.D. Sărdărescu $1^{*}$ \\ ${ }^{1}$ National Research and Development Institute for Biotechnology in Horticulture, \\ Stefanesti - Arges, Romania \\ *Corresponding author email: ionela.sardarescu@incdbh-stefanesti.ro
}

\begin{abstract}
More than 80 viruses are reported as causing damage to the grapevine, but some of them are rare and cause negligible damages. However, other viruses are veritable pathogens for this crop, affecting the production quantity and quality, such as: grapevine leafroll-associated virus serotype 1+3 (GLRaV-1+3), grapevine fleck virus (GFkV), and grapevine fanleaf virus (GFLV). In this study, we present the effects of Serlac V, Growspore Vita and Nutryaction biostimulants on the grapevine plants belonging to 'Valerien' and 'Italia 93 Mf.' genotypes infected with GFkV and 'Cardinal 74 Mf.' genotype infected with GLRaV-1+3 and GFkV. Determinations have been made regarding the content of assimilating pigments in leaves (chlorophyll $a$, chlorophyll $b$, and carotenoids), a diameter of the cane and of the pith, leaf surface, stomata length and ostioles opening.
\end{abstract}

Keywords: organic matter, stress factor, virus serotypes, active ingredient, biostimulators

\section{Introduction}

The grapevine is a horticultural crop with worldwide major economic influence. The viticultural market is considered to be one of the most dynamic and fast-growing from horticultural market in the recent years. Therefore, timely monitoring of the factors that can strongly affect the plant growth and the production quality, mainly the control of causative agents of grapevine diseases, have a particularly importance for grapevine culture.

Grapevine can be affected by various phytopathogenic agents: fungi, bacteria, viruses, viroids, and phytoplasmas.

Agent of viruses represent a group of special pathogens of grapevine. More viruses have been reported in the grapevine than in any other crop, with more than 80 viruses identified in the genus Vitis, grouped into 18 families and 34 genres (Martelli, 2018). Some of these are rare and cause minor damages. Other viruses are true pathogens of grapevines and agents of diseases with economic impact, affecting the quantity and quality of production, such as: grapevine fanleaf virus (GFLV), grapevine leafroll-associated virus serotypes 1+3 (GLRaV$1+3)$ and grapevine fleck virus (GFkV).

Because of the physiological and metabolic modifications that are produced, the virus infection has negative consequences over the plant: reduction of vigor and production, decline, delayed entry into vegetation and fruiting, decreased graft compatibility and rooting capacity, changes in the composition of the grapes and the aromatic profile. Assessing the effects of viruses and virus diseases is not as easy as one might think, because the severity of the symptoms varies from one virus to another (even depending on the severity of the 
strain), the genotype and the age of the infected grapevine and, as well, of the environmental conditions (Naidu et al., 2015).

This paper aimed to evaluate the action of the biostimulants Serlac V, Growspore Vita and Nutryaction on the grapevine plants (V. vinifera L.) infected with GFkV and GLRaV-1+3. These viruses are widespread in the vineyards of our country and are often found in complex infections affecting different grapevine genotypes (Buciumeanu et al., 2015).

Serlac V is a biostimulant recommended for vegetable crops, grapevines, ornamental plants, citrus, olive, strawberry for the protection and recovery of plants in the presence of virus infections.

Growspore Vita is useful for grapevine and can influence and improve many of the biochemical processes of the plants (chlorophyll synthesis, photosynthesis; cellular respiration; protein synthesis; cellular relaxation processes; water absorption; prevents thermal and/or water stress; prevents stress caused by pathogens; prevents iron, manganese and zinc deficiencies and last but not the least increases the yield and quality of plants).

Nutryaction is an organic fertilizer with fluid nitrogen (yeast extract containing brown algae) that prevents biotic and abiotic stress. It is allowed in organic farming under legislative Decree no. 75/2010. Nutryaction helps the rapid growth of all plant species, due to the special formula based on organic molecules of plant origin with low molecular weight and has a positive effect on the photosynthetic processes. Its application is also recommended to reduce the stress during the cold springs. When applied to the soil it also allows a high activity of useful microflora and stimulates its development. It is best used in combination with all microorganism-based products (Line Greenspore), before or simultaneously with their use, allowing the activation of these products earlier and more effectively. This association guarantees a better preventive action against biotic stress and stimulates the development of the foliar apparatus and roots.

\section{MATERIALS AND METHODS}

During the research, three genotypes of grapevine were studied, from the collection of virusinfected plants located in the greenhouse, belonging to NRDIBH Stefanesti: 'Valerien' and 'Italia 93 Mf.' (infected with GFkV) and 'Cardinal 74 Mf.' (with complex virus infection, GLRaV-1+3 and GFkV). Grapevine plants, 3 years old, planted on their roots, were kept in vegetation pots with a capacity of $0.5 \mathrm{~L}$.

The treatments with the biostimulants Serlac V, Growspore Vita + Nutryaction were sprayed in the morning, at 08:30, between April and August 2019, according to the treatment scheme presented in Table 1.

Table 1. Ecological treatment scheme with Serlac V and Growspore Vita

\begin{tabular}{|c|c|l|}
\hline \multirow{2}{*}{ No. } & \multicolumn{2}{|c|}{ Treatment } \\
\cline { 2 - 3 } & Application date & \multicolumn{1}{c|}{ Biostimulators } \\
\hline 1. & $04 / 08 / 2019$ & Serlac V $(3 \mathrm{ml}$ Serlac V homogenized with $500 \mathrm{ml}$ water $)$ \\
\hline 2. & $04 / 22 / 2019$ & $(1 \mathrm{ml}$ Growspore Vita +1 ml Nutryaction $)+500 \mathrm{ml}$ water \\
\hline 3. & $05 / 08 / 2019$ & Serlac V $(3 \mathrm{ml}$ Serlac V homogenized with $500 \mathrm{ml}$ water $)$ \\
\hline 4. & $05 / 22 / 2019$ & $(1 \mathrm{ml}$ Growspore Vita $+1 \mathrm{ml}$ Nutryaction $)+500 \mathrm{ml}$ water \\
\hline 5. & $06 / 07 / 2019$ & Serlac V $(3 \mathrm{ml}$ Serlac V homogenized with $500 \mathrm{ml}$ water $)$ \\
\hline 6. & $06 / 21 / 2019$ & $(1 \mathrm{ml}$ Growspore Vita $+1 \mathrm{ml}$ Nutryaction $)+500 \mathrm{ml}$ water \\
\hline 7. & $06 / 28 / 2019$ & Serlac V $(3 \mathrm{ml}$ Serlac V homogenized with $500 \mathrm{ml}$ water $)$ \\
\hline 8. & $07 / 23 / 2019$ & $(1 \mathrm{ml}$ Growspore Vita +1 ml Nutryaction $)+500 \mathrm{ml}$ water \\
\hline
\end{tabular}


Two variants were studied. One of them (V1), was represented by untreated virus-infected grapevine plants (control) and the other (V2) by the ecologically treated virus-infected plants.

During the experiment were made biochemical, biometric and physiological determinations. Biochemical determinations were performed both during the growing phase and the dormancy. During the vegetation period, the content of the foliar material in chlorophyll pigments (chlorophyll $a$, chlorophyll $b$ ) and carotenoids was checked (Holm, 1954). The content of assimilatory pigments was expressed in $\mathrm{mg} / \mathrm{g}$ fresh matter (fm).

In order to evaluate the degree of cane maturation, determinations regarding the content in soluble carbohydrates, starch, and total carbohydrates were made during the winter. The concentration of sugars from the canes was determined by the anthrone method. The results were expressed as a percentage of glucose in the dry matter (Bugnon and Bessis, 1968).

Biometric determinations were performed concerning the diameter of the wood and the pith (in February after the frost period) and the leaf surface (at the start of the ripening phase when the vegetative apparatus of the grapevine shows a maximum development).

An electronic caliper was used to determine the pith/wood ratio (R) and the obtained data were interpreted after Alexiu et al., (2002). At $\mathrm{R}>1$ the wood is incompletely matured; $\mathrm{R} \approx 1$ the wood is partially matured, and at $\mathrm{R}<1$ the wood is well matured.

The foliar surface was measured using the leaf blade length method (Kișin method) based on the following formula $S=\pi \times d 2 / 4$, where $S=$ leaf surface; $\pi=3,14 ; d 2=$ the distance between the tip of the main lobe and the lower edge of the foliar surface (Oprea and Carabulea, 2003). For this determination the fourth leaf from the base of the shoot was used, when the vegetative apparatus of the grapevine showed maximum development, that is after the ripening phase. This method has the advantage that the leaf area can be determined without the leaf being detached from the shoot.

Biometric determinations on stomata length and ostiole opening were performed in June (during the active growth of plants). Samples for optical microscopy were obtained by applying a thin layer of transparent nail polish (Gokbayrak et al., 2008). For the determination of the degree of opening and the length of the stomata, a microscope (Olympus) was used, equipped with an Olympus photo-camera and "Quick Photo Micro" software.

The results were statistically analyzed using SPSS, version 21, according to the One-Way ANOVA, LSD test.

\section{RESULTS AND DISCUSSIONS}

The content in assimilating pigments showed differences between V1 and V2, in both stages of the analysis (June $26^{\text {th }}$ - during the period of active growth and September $19^{\text {th }}$ - two months after the completion of treatments, at the end of the vegetation period). In the first stage, for 'Italia 93 Mf.' genotype chlorophyll $a$ and $b$ were higher in V2 and for 'Cardinal 74 Mf.' chlorophyll $b$ was higher in V2 than in V1. For the 'Valerien' genotype, the content of assimilating pigments was higher at V1 (probably the leaves of the plants from V2 started the senescence process earlier due to the application of biostimulants). In the second stage of analysis, for 'Valerien' and 'Italia 93 Mf.' genotypes, all fractions of assimilating pigments were higher at V2. Significant differences were recorded in the first stage in the case of carotenoids (for 'Cardinal $74 \mathrm{Mf}$. '), and in the second stage in the case of chlorophyll $a$ (for 'Valerian'), chlorophyll $a$ and carotenoids (for 'Italy 93 Mf.'), chlorophyll $b$ and chlorophyll $a /$ chlorophyll $b$ ratio (for 'Cardinal 74 Mf.'). 
The influence of biostimulator treatments on the content of assimilating pigments in virusinfected plants was mainly determined by grapevine genotype and phenophase (Table 2).

Table 2. Content of assimilatory pigments at grapevine plants with viral infection. The values represent the mean $\pm \mathrm{SD}$, the letters indicate significant differences as compared to the control for the significance threshold $\mathrm{p}<0.05$.

\begin{tabular}{|c|c|c|c|c|c|}
\hline \multirow{3}{*}{$\begin{array}{c}\text { Genotype/ } \\
\text { Virus } \\
\text { infection }\end{array}$} & \multirow{3}{*}{ Assimilating pigments } & \multicolumn{4}{|c|}{ Data } \\
\hline & & \multicolumn{2}{|c|}{$06 / 26 / 2019$} & \multicolumn{2}{|c|}{$09 / 19 / 2019$} \\
\hline & & V1 & $\mathrm{V} 2$ & V1 & V2 \\
\hline \multirow{4}{*}{$\begin{array}{c}\text { 'Valerien'/ } \\
\text { GFkV }\end{array}$} & Chlorophyll $a(\mathrm{mg} / \mathrm{g} \mathrm{fm})$ & $1.10 \pm 0.13 \mathrm{a}$ & $0.90 \pm 0.28 \mathrm{a}$ & $0.76 \pm 0.20 \mathrm{a}$ & $1.29 \pm 0.11 \mathrm{~b}$ \\
\hline & Chlorophyll $b(\mathrm{mg} / \mathrm{g} \mathrm{fm})$ & $0.55 \pm 0.46 a$ & $0.53 \pm 0.73 a$ & $0.41 \pm 0.08 \mathrm{a}$ & $0.60 \pm 0.08 \mathrm{a}$ \\
\hline & Carotenoids (mg/g fm) & $0.70 \pm 0.74 a$ & $0.55 \pm 0.21 \mathrm{a}$ & $0.47 \pm 0.12 \mathrm{a}$ & $0.79 \pm 0.08 \mathrm{a}$ \\
\hline & $\mathrm{Cl} a / \mathrm{Cl} b$ & $1.98 \pm 0.64 a$ & $1.66 \pm 0.38 \mathrm{a}$ & $1.85 \pm 0.12 \mathrm{a}$ & $2.15 \pm 0.13 \mathrm{a}$ \\
\hline \multirow{4}{*}{$\begin{array}{l}\text { 'Italia } 93 \\
\text { Mf' / GFkV }\end{array}$} & Chlorophyll $a(\mathrm{mg} / \mathrm{g} \mathrm{fm})$ & $0.91 \pm 0.40 \mathrm{a}$ & $0.91 \pm 0.47 \mathrm{a}$ & $0.81 \pm 0.002 \mathrm{a}$ & $1.01 \pm 0.01 \mathrm{~b}$ \\
\hline & Chlorophyll $b(\mathrm{mg} / \mathrm{g} \mathrm{fm})$ & $0.51 \pm 0.23 a$ & $0.53 \pm 0.33 a$ & $0.40 \pm 0.004 a$ & $0.48 \pm 0.00 \mathrm{a}$ \\
\hline & Carotenoids $(\mathrm{mg} / \mathrm{g} \mathrm{fm})$ & $0.61 \pm 0.21 \mathrm{a}$ & $0.55 \pm 0.47 \mathrm{a}$ & $0.49 \pm 0.00 \mathrm{a}$ & $0.62 \pm 0.004 \mathrm{~b}$ \\
\hline & $\mathrm{Cl} a / \mathrm{Cl} b$ & $1.78 \pm 0.30 \mathrm{a}$ & $1.66 \pm 0.38 \mathrm{a}$ & $2.07 \pm 0.02 \mathrm{a}$ & $2.09 \pm 0.02 \mathrm{a}$ \\
\hline \multirow{4}{*}{$\begin{array}{c}\text { 'Cardinal } \\
74 \mathrm{Mf} \cdot . / \\
\text { GFkV + } \\
\text { GLRa } \\
\text { V-1+3 }\end{array}$} & Chlorophyll $a(\mathrm{mg} / \mathrm{g} \mathrm{fm})$ & $0.54 \pm 0.31 \mathrm{a}$ & $0.73 \pm 0.11 \mathrm{a}$ & $1.02 \pm 0.06 \mathrm{a}$ & $0.86 \pm 0.10 \mathrm{a}$ \\
\hline & Chlorophyll b (mg/g fm) & $0.54 \pm 0.31 \mathrm{a}$ & $0.47 \pm 0.61 \mathrm{a}$ & $0.49 \pm 0.01 \mathrm{a}$ & $0.44 \pm 0.04 \mathrm{~b}$ \\
\hline & Carotenoids $(\mathrm{mg} / \mathrm{g} \mathrm{fm})$ & $0.68 \pm 0.20 \mathrm{a}$ & $0.42 \pm 0.69 \mathrm{~b}$ & $0.62 \pm 0.04 \mathrm{a}$ & $0.53 \pm 0.06 \mathrm{a}$ \\
\hline & $\mathrm{Cl} \mathrm{a} / \mathrm{Cl} \mathrm{b}$ & $2.01 \pm 0.41 \mathrm{a}$ & $1.58 \pm 0.54 \mathrm{a}$ & $2.10 \pm 0.08 \mathrm{a}$ & $1.94 \pm 0.04 b$ \\
\hline
\end{tabular}

The canes content in soluble carbohydrates and starch for all the studied genotypes did not show significant differences between V1 and V2, although the 'Cardinal 74 Mf. ' genotype recorded an increased content of soluble carbohydrates and starch in V2 as compared to V1. In the case of the 'Valerian' genotype, the total carbohydrates content was reduced to V2 as compared to the control, both the content of soluble sugars and starch being lower. The 'Italia 93 Mf.' genotype recorded a decrease in the soluble carbohydrates content and an increase in the starch content at V2 comparatively to V1 (Figure 1).

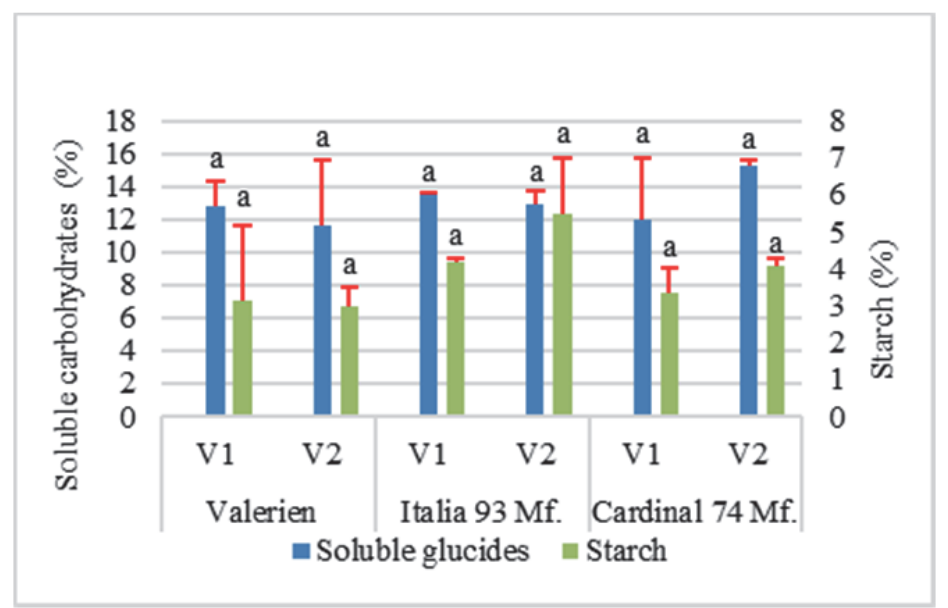

Figure 1. The influence of ecological treatments on the degree of maturation. The values represent the mean $( \pm S D)$, the letters indicate significant differences as compared to the control for the significance threshold $\mathrm{p}<0.05$ 


\section{Biometric determinations}

The values of the pith/wood ratio were less than 1 in both variants regardless of genotype and virus infection and showed significant differences as compared to the control in case of 'Valerian' genotype for cane diameter and in case of 'Italy 93 Mf.' genotype for pith/wood ratio. In case of 'Cardinal $74 \mathrm{Mf}$.' genotype did not show significant differences from the control (Figure 2).

Table 3. Foliar surface, degree of ostioles opening and length of the stomata. The values represent the mean \pm SD, the letters indicate significant differences as compared to the control for the significance threshold $\mathrm{p}<0.05$.

\begin{tabular}{|c|l|c|c|}
\hline $\begin{array}{c}\text { Genotype/Virus } \\
\text { infection }\end{array}$ & \multicolumn{1}{|c|}{$\begin{array}{c}\text { Biometric and } \\
\text { physiological } \\
\text { measurements }\end{array}$} & V1 & V2 \\
\hline \multirow{3}{*}{ 'Valerien'/GFkV } & Foliar surface $\left(\mathrm{cm}^{2}\right)$ & $84.50 \pm 8.66 \mathrm{a}$ & $82.07 \pm 8.11 \mathrm{a}$ \\
\cline { 2 - 4 } & Ostioles opening $(\mu \mathrm{m})$ & $8.93 \pm 2.37 \mathrm{a}$ & $11.00 \pm 1.06 \mathrm{~b}$ \\
\cline { 2 - 4 } & Stomata length $(\mu \mathrm{m})$ & $30.80 \pm 1.44 \mathrm{a}$ & $31.70 \pm 1.42 \mathrm{a}$ \\
\hline \multirow{3}{*}{ 'Italia 93 Mf.' /GFkV } & Foliar surface $\left(\mathrm{cm}^{2}\right)$ & $84.90 \pm 0.10 \mathrm{a}$ & $83.90 \pm 8.50 \mathrm{a}$ \\
\cline { 2 - 4 } & Ostioles opening $(\mu \mathrm{m})$ & $9.10 \pm 0.10 \mathrm{a}$ & $7.07 \pm 0.65 \mathrm{~b}$ \\
\cline { 2 - 4 } & Stomata length $(\mu \mathrm{m})$ & $26.80 \pm 1.20 \mathrm{a}$ & $27.30 \pm 3.10 \mathrm{a}$ \\
\hline \multirow{2}{*}{ 'Cardinal 74 Mf.'/ } & Foliar surface $\left(\mathrm{cm}^{2}\right)$ & $114.60 \pm 48.20 \mathrm{a}$ & $113.13 \pm 25.75 \mathrm{a}$ \\
\cline { 2 - 4 } GFkV + GLRaV-1+3 & Ostioles opening $(\mu \mathrm{m})$ & $6.50 \pm 0.30 \mathrm{a}$ & $6.87 \pm 0.55 \mathrm{a}$ \\
\cline { 2 - 4 } & Stomata length $(\mu \mathrm{m})$ & $26.80 \pm 1.20 \mathrm{a}$ & $27.30 \pm 3.10 \mathrm{a}$ \\
\hline
\end{tabular}

The stomata are specialized structures, being located in the epidermis, with a role in the exchange of gases between the plant and the external environment, as well as in the release of water vapor. With their help, the carbon dioxide needed for assimilation and the oxygen needed for respiration enter the plant. The opening of the ostiole is determined by monovalent cations that actively enter from the annexed cells into the vacuoles of the stomatal cells, producing the increase of their osmotic potential. This process allows water to enter the stomatal cells and to increase their turgescence and finally to open the ostioles (Gâdea, 2003).

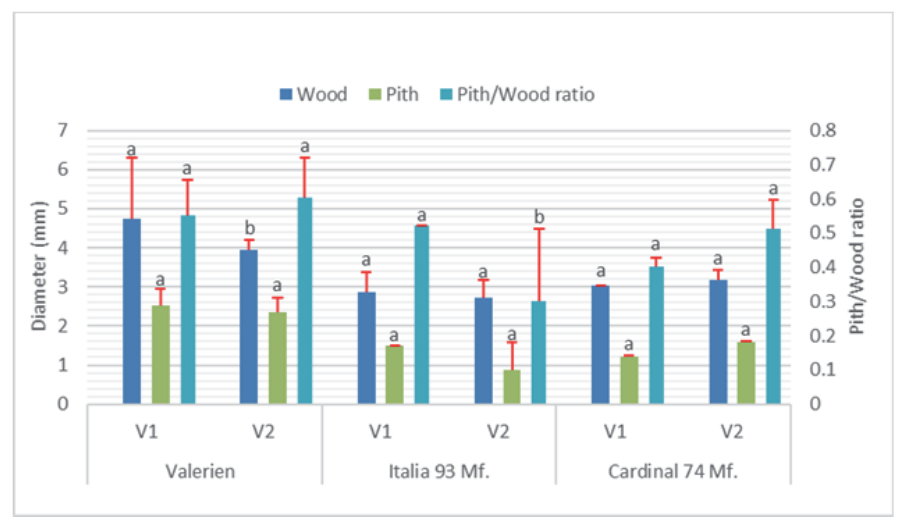

Figure 2. Pith diameter, cane diameter and pith/wood ratio. The values represent the mean $( \pm S D)$, the letters indicate significant differences as compared to the control for the significance threshold $\mathrm{p}<0.05$.

Application of the organic products led to significant increases for the 'Valerian' and 'Italy 93 Mf.' genotypes regarding the degree of opening of the ostioles in variant V2 as compared 
to V1. Leaf area values were slightly lower at V2 as compared to V1 and in the case of this indicator, no significant differences were registered (Table 3).

Biostimulants improve the general health, vitality, and growth of plants and protect them against infections (Drobek et al., 2019). From agricultural biostimulants very important are seaweed extract derivatives (obtained from green, red or brown algae) and hydrolysed proteins (mostly constitutes by free amino acids and peptides), (Craigie, 2011 quoted by Szczepanek et al., 2018).

\section{CONCLUSIONS}

The content in assimilating pigments of virus-infected grapevine plants registered a significant difference in the variant treated with biostimulants as compared to the control (untreated plant) towards the end of the vegetation period in the 'Italia $93 \mathrm{Mf}$ '. and 'Cardinal 74 Mf.' genotypes.

The content of carbohydrates from the canes (soluble glucides and starch) did not show significant differences between treated and untreated plants in any of the studied grapevine genotypes.

In the case of biometric determinations, significant differences were obtained only in terms of ostioles opening at the GFkV- infected 'Valerien' and 'Italia 93 Mf.' genotypes.

It is recommended to continue the research concerning the treatments with different doses of bioactive products on grapevines grown in the field, under the influence of various biotic and abiotic stress factors.

\section{REFERENCES}

1. Alexiu V., Neblea M., Sumedrea D., Vișoiu E., Tița I., Posedaru A., Richițeanu A., Cristescu C., Dumitriu I.C., and Cujbescu I. (2002). Caiet de practică horticolă, Editura Universitatea din Pitești, ISBN 973 - 8024 -10 - 2.

2. Buciumeanu E.C., Guță I.C., Nedelea G., and Tănăsescu C. (2015). Evaluarea stării fitosanitare la soiuri autohtone de viță-de-vie în Regiunea viticolă Dealurile Munteniei Și Olteniei. Hortus 14:205-208.

3. Bugnon F., and Bessis R. (1968). Biologie de la vigne, acquisitions récentes et problèmes actuels. Ed. Masson et Cie, Paris.

4. Craigie J. (2011). Seaweed extract stimuli in plant science and agriculture. Journal of Applied Phycology, 23:371-393, 10.1007/s10811-010-9560-4.

5. Drobek M., Frąc M., and Cybulska J. (2019). Plant Biostimulants: Importance of the Quality and Yield of Horticultural Crops and the Improvement of Plant Tolerance to Abiotic Stress - A Review. Agronomy 9(6):335. https://doi.org/10.3390/agronomy9060335.

6. Gâdea Ş. (2003). Fiziologie vegetală, Ed. Academic Pres, Cluj-Napoca.

7. Gokbayrak Z., Dardeniz A., and Bal M. (2008). Stomatal density adaptation of grapevine to windy conditions. Trakia Journal of Sciences 6:18-22.

8. Holm G. (1954). Chlorophyll mutations in barley. Acta Agriculturae Scandinavica, 4(1): 457-471.

9. Martelli G.P. (2018). Where grapevine virology is heading to. Proceedings of the 19th ICVG, Santiago, Chile, April 9-12, 10-15

10. Naidu R.A., Bagewadi B., Walker L., Swamy P., and Schultz A. (2015). Tobacco ringspot virus in a wine grape (Vitis vinifera) cultivar in Washington State. Extended abstracts 18th ICVG Meeting, Ankara, Turkey; 7-11 September 2015, 24-25.

11. Oprea A., and Carabulea O. (2003). Viticultura: lucrări practice. Universitatea de Ştiinţe Agronomice şi Medicină Veterinară.,

12.Szczepanek M., Wszelaczyńska E., and Pobereżny J. (2018), Effect of seaweed biostimulant application in spring wheat. AgroLife Scientific Journal 7(1):131-136. ISSN 2285-5718.

13. http://www.microspore.com/wp-content/uploads/2015/02/greenspore.pdf

14. https://www.mapryser.com/agriser/eng/files/Serlac-V-extreme-eng.pdf 